\title{
THE IDENTITY AND TAXONOMIC STATUS OF SITARIS LATIVENTRIS SCHAUFUSS, 1861 AND SITARIS MELANURUS KÜSTER, 1849, TWO ENIGMATIC IBERIAN TAXA (COLEOPTERA, MELOIDAE)
}

\author{
J. L. Ruiz ${ }^{1}$, M. A. Bologna² \& M. García-París ${ }^{3 *}$
}

\begin{abstract}
J. L. Ruiz, M. A. Bologna \& M. García-París. 2013. The identity and taxonomic status of Sitaris lativentris Schaufuss, 1861 and Sitaris melanurus Küster, 1849, two enigmatic Iberian taxa (Coleoptera, Meloidae). Grael/sia, 69(2): 169-178.

Extensive morphological variability in Nemognatinae has often led to proliferation of species descriptions. Most species of Nemognathinae are seldom encountered in nature and some species remain only known by the specimens used for the original descriptions. Two examples of this problem are represented by Sitaris lativentris Schaufuss, 1861 and Sitaris melanurus Küster, 1849, both described from Spain. The rediscovery of specimens morphologically assignable to $S$. lativentris in southern Spain, and a careful reading of the original description of $S$. melanurus, allow us to shed light on the taxonomic status of these enigmatic taxa. Sitaris lativentris has been considered a synonym of Sitaris solieri Pecchioli, 1840 until now; however, neither the lectotype of $S$. lativentris (here designated), nor the newly found specimens morphologically assignable to $S$. lativentris, correspond to $S$. solieri, except in coloration. Alternatively, comparisons between $S$. lativentris and $S$. muralis did not render any differences, except in the pattern of elytral coloration and coloration of the pilosity, both variable in other species of Nemognathinae. Therefore S. lativentris is hereby synonymised with S. muralis (new synonymy). The identity of Sitaris melanurus has been overlooked by most researchers, probably because the type specimens seem to be lost. However, the original description provides sufficient information to discard the inclusion of the taxon in Sitaris. Morphological characters presented in the description correspond to traits that, among western European sitarine beetles, are only present in Stenoria apicalis (Latreille, 1804). Küster's (1849) description corresponds to one of the most frequent color variants of this species. As a consequence we include the name $S$. melanurus as a new synonym of $S$. apicalis.
\end{abstract}

Key words: Coleoptera; Meloidae; Sitaris; Taxonomy; Morphological variability; Scientific Collections; New synonymies; Lectotypes; Iberian Peninsula; Spain.

\footnotetext{
Instituto de Estudios Ceutíes. Paseo del Revellín, 30. Apartado 593. 51080 Ceuta. España. euserica@hotmail.com

2 Dipartimento di Scienze Ambientale. Università degli Studi "Roma Tre". Viale G. Marconi 446. 00146 Roma. Italia. marcoalberto.bologna@uniroma3.it

3 Departamento de Biodiversidad y Biología Evolutiva. Museo Nacional de Ciencias Naturales, MNCN-CSIC. c/ José Gutiérrez Abascal, 2. 28006. Madrid. España.mparis@mmcn.csic.es

* Author for correspondence: mparis@mncn.csic.es
} 


\section{RESUMEN}

J. L. Ruiz, M. A. Bologna \& M. García-París. 2013. The identity and taxonomic status of Sitaris lativentris Schaufuss, 1861 and Sitaris melanurus Küster, 1849, two Iberian enigmatic taxa (Coleoptera: Meloidae). Graellsia, 69(2): 169-178 (in Spanish).

La amplia varibilidad morfológica en Nemognathinae a menudo ha originado una proliferación en la descripción de especies distintas. La mayoría de la especies de Nemognathinae rara vez se encuentran en la naturaleza y algunas sólo son conocidas por los ejemplares utilizados en las descripciones originales. Dos ejemplos de este problema son los casos de Sitaris lativentris Schaufuss, 1861 y Sitaris melanurus Küster, 1849, ambas descritas de España. El redescubrimiento de ejemplares morfológicamente asignables a S. lativentris en el sur de España, y una detallada lectura crítica de la descripción original de $S$. melanurus, nos permiten dilucidar el estatus taxonómico de estos taxones enigmáticos. Sitaris lativentris ha sido considerado hasta ahora un sinónimo de Sitaris solieri Pecchioli, 1840; sin embargo, ni el lectotipo de $S$. lativentris (aquí designado) ni los nuevos especímenes encontrados asignables a $S$. lativentris, se corresponden con $S$. solieri, excepto en que ambos presentan una coloración similar. Alternativamente, el estudio comparativo de S. lativentris y Sitaris muralis (Forster, 1771) no muestra diferencias entre ellas, excepto en el patrón cromático elitral y la coloración de la pilosidad, ambos caracteres ampliamente variables en otras especies de Nemognathinae. Por tanto, se sinonimiza S. lativentris con S. muralis (nuevo sinónimo). La identidad de Sitaris melanurus ha sido pasada por alto por la mayoría de los investigadores, posiblemente porque los ejemplares tipo parecen estar perdidos. No obstante, la descripción original ofrece suficiente información para descartar la adscripción de este taxón a Sitaris. Los caracteres morfológicos expuestos en la descripción corresponden a rasgos que, en el ámbito de los sitarinos europeos, se encuentran sólo en Stenoria apicalis (Latreille, 1804). La descripción de Küster (1849) corresponde a una de la variantes cromáticas más frecuentes en esa especie. Como consecuencia, incluimos el nombre $S$. melanurus como un nuevo sinónimo de $S$. apicalis.

Palabras-clave: Coleoptera; Meloidae; Sitaris; Taxonomía; Variabilidad morfológica; Colecciones científicas; Nuevas sinonimias; Lectotipos; Península Iberica, España.

\section{Introduction}

Several species of Meloidae parasitoids on solitary bees, show during the adult phase various levels of morphological modifications with respect to the typical "meloid bauplan", which is easily recognizable in the speciose tribes Mylabrini and Lyttini (Bologna, 1991). These modifications are particularly obvious in some genera of Nemognathinae, namely in the sitarine lineage of the tribe Nemognathini (Bologna, 1991; Bologna \& Pinto, 2002; Bologna et al., 2008). In this tribe elytral reduction and general body shape modification are common (e.g. Allendesalazaria Martínez de la Escalera, 1910, Apalus Fabricius, 1775, Glasunovia Semenov, 1895, Hornia Riley, 1877, Nyadatus Aksentjev, 1981, Sitaris Latreille, 1802, Sitarobrachys Reitter, 1883, Sitaromorpha Dokhtouroff, 1890, and Stenoria Mulsant, 1857) (Pinto \& Bologna, 1999; Bologna \& Pinto, 2002). Moreover, some species in those gene-ra show a surprisingly high intraspecific variability in external morphological traits (MacSwain, 1956, 1958; Pardo Alcaide,
1958; Bologna, 1991), which otherwise are generally constant in Meloidae, including head, prothorax and elytral shape, antennae and leg width and length, and coloration of body parts and vestiture (Pardo Alcaide, 1958; Kaszab, 1963; Bologna, 1991). This variability has often led to taxonomic confusion and in many cases proliferation of species descriptions often representing the morphological diversity within single species [see for example the synonym list of Sitarobrachys thoracicus (Kraatz, 1862) (Bologna, 1994, 2008)]. To complicate the problem further, species of these groups are seldom encountered in nature, adult activity being limited to a few days, generally restricted around bee nests where larval development occurs, and therefore comparative series are often limited (e.g. Bologna, 1991; Schawaller, 1996; Bologna \& Aberlenc, 2002; Bologna \& Pinto, 2002). As a consequence many species descriptions are based on single or few specimens and many of these taxa remain known by only those specimens (e.g. Escherich, 1897; Martínez de la Escalera, 1906; Kaszab, 1953; Pardo Alcaide, 1961). 
Sitaris lativentris Schaufuss, 1861 and Sitaris melanurus Küster, 1849, both described from Spain, represent a good example. Descriptions of both taxa are quite precise and permit an accurate identification, but no other specimens were found again after the descriptions. The nomenclatural history of these names is diverse, while $S$. melanurus was used in recent catalogues (Bologna, 2008; García-París et al., 2010), the name S. lativentris was placed in the synonym list of Sitaris solieri Pecchioli, 1840 without any justification (Escherich, 1897; Bologna, 1991).

The collection of new specimens morphologically assignable to $S$. lativentris in southern Spain, the availability of series of Iberian specimens of $S$. muralis and $S$. solieri for comparison (Appendix I), the examination of type material of most Sitaris taxa (Bologna, in prep.), and a careful reading of the original description of $S$. melanurus, allow us to shed light on the taxonomic status of these enigmatic taxa.

\section{The taxonomic status of Sitaris lativentris Schaufuss, 1861}

Sitaris lativentris was described from southern Spain (Type locality: "Hisp. mer."; Schaufuss, 1861: 49), based on an undetermined number of specimens (more than one). Escherich (1897) included the name in the synonym list of $S$. solieri without discussion - probably influenced by the colouration pattern of the specimens described (Schaufuss, 1861) and by the comments of Schaufuss (1870: 47)-, where it has remained since then (Mader, 1927; Bologna, 1991, 2008; GarcíaParís et al., 2010). Borchmann (1917: 144) disagreed and treated $S$. lativentris as an independent taxon, indicating "Andalusien" as its geographic range, as Beauregard (1890) had already pointed out. The original description of $S$. lativentris does not include any information about the tarsal claws structure. Presence or absence of a row of teeth in the ventral margin of the upper blade of tarsal claws, allows a readly assignation of specimens to the species complexes related to either $S$. solieri (with a row of teeth) or to $S$. muralis (without teeth) (Bologna, 1991).

Recent field surveys in southern Spain led to discovery of a few specimens that correspond precisely to the description of $S$. lativentris. These specimens are two males (Fig. 1) collected in Sorvilán $\left(36^{\circ} 47^{\prime} 38.35^{\prime \prime} \mathrm{N}-3^{\circ} 16^{\prime} 01.91\right.$ 'O) (Province of Granada, Spain, 12-IX-2005, J.L. Ruiz leg.), which were found in strict microsympatry with three specimens of typical S. muralis (Appendix I). Both series of Sitaris were found together inside the village of Sorvilán, resting on one of the ancient walls of the church at mid-day. Subsequent visits to the locality during the same dates of 2006, 2007 and 2008 yielded more specimens of typical $S$. muralis, but none morphologically similar to $S$. lativentris or $S$. solieri (Appendix I).

We had the opportunity of examining a female syntype of S. lativentris (Fig. 2) held at the collection of the Magyar Természettudományi Múzeum (HNHM, Budapest), and to compare it with specimens of $S$. solieri, $S$. muralis and with the atypical specimens from Sorvilán. This specimen is pinned with the following labels: (a) "Hispania mer., Staudinger" (white, handwritten, rectangular); (b) "Holotypus 1861, Sitaris lativentris, L.W. Schaufuss (white with red contour line, rectangular, handwritten, with "Holotypus" red printed). However, Schaufuss (1861) did not designate a holotype for $S$. lativentris, and based on the original description the type series included more than one specimen. Consequently the "Holotypus" label was added posteriorly. In order to avoid further taxonomic problems and in accordance with article 74.7.3 of the International Code of Zoological Nomenclature (ICZN, 1999), we designate here the specimen above indicated (Fig. 2) as lectotype of $S$. lativentris (present designation). We add to this specimen the following label: "Lectotypus / Sitaris lativentris Schaufuss, 1861 / Ruiz, Bologna \& $\mathrm{G}^{\mathrm{a}}$ París des. 2013" (red printed label).

The specimens from Sorvilán are identical in all aspects to the lectotype of $S$. lativentris, including color pattern, pilosity coloration and shape, antennae morphology and length, and structure of tarsal claws. A brief description follows: total length: 10.8-11.9 mm; head and thorax black, shiny; legs with tibiae and tarsi orange-yellow, except the apical tarsal segment, yellowish brown, femora dark brown with distal portions lighter, metafemora with a narrow longitudinal yellowish broad line in their ventral margin; upper blade of tarsal claws ventrally smooth or only with one or few faint teeth; antennae with first segment black, shiny, the second dark reddish brown, all other segments (IIIXI) dark brown, almost black, not shiny; labrum 

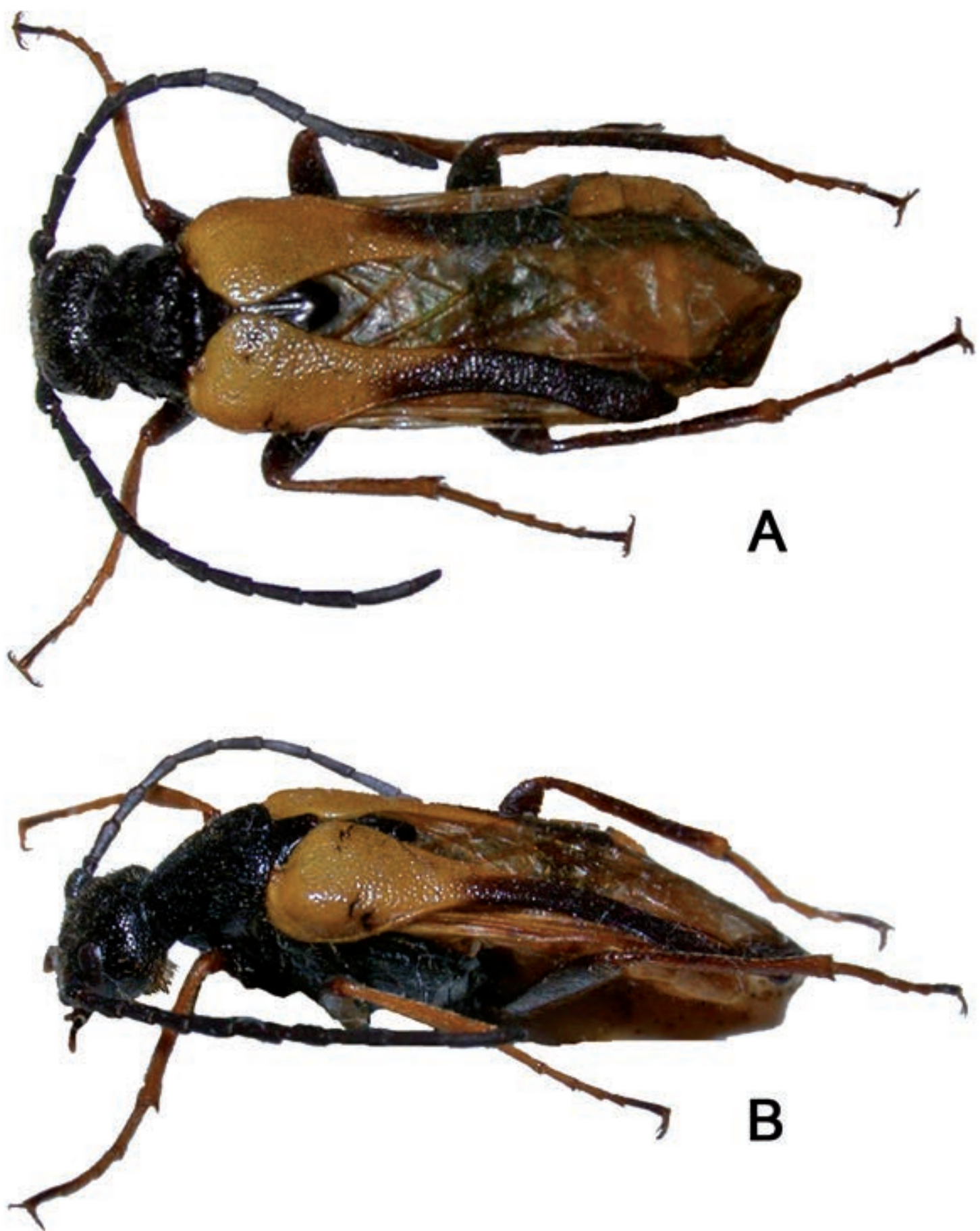

Fig. 1.- Male specimen of $S$. muralis, perfectly fitting the description of $S$. lativentris, recently collected in Sorvilán (36²7'38.35"N - 3¹6'01.91"O) (Province of Granada, Spain) (J.L. Ruiz leg.). A. Dorsal view. B. Lateral view.

Fig. 1.- Ejemplar macho de S. muralis, totalmente coincidente con la descripción de S. lativentris, recientemente colectado en Sorvilán $\left(36^{\circ} 47^{\prime} 38.35^{\prime \prime} N-3^{\circ} 16^{\prime} 01.91^{\prime \prime O}\right)$ (Provincia de Granada, España) (J.L. Ruiz leg.). A. Vista dorsal. B. vista lateral. 

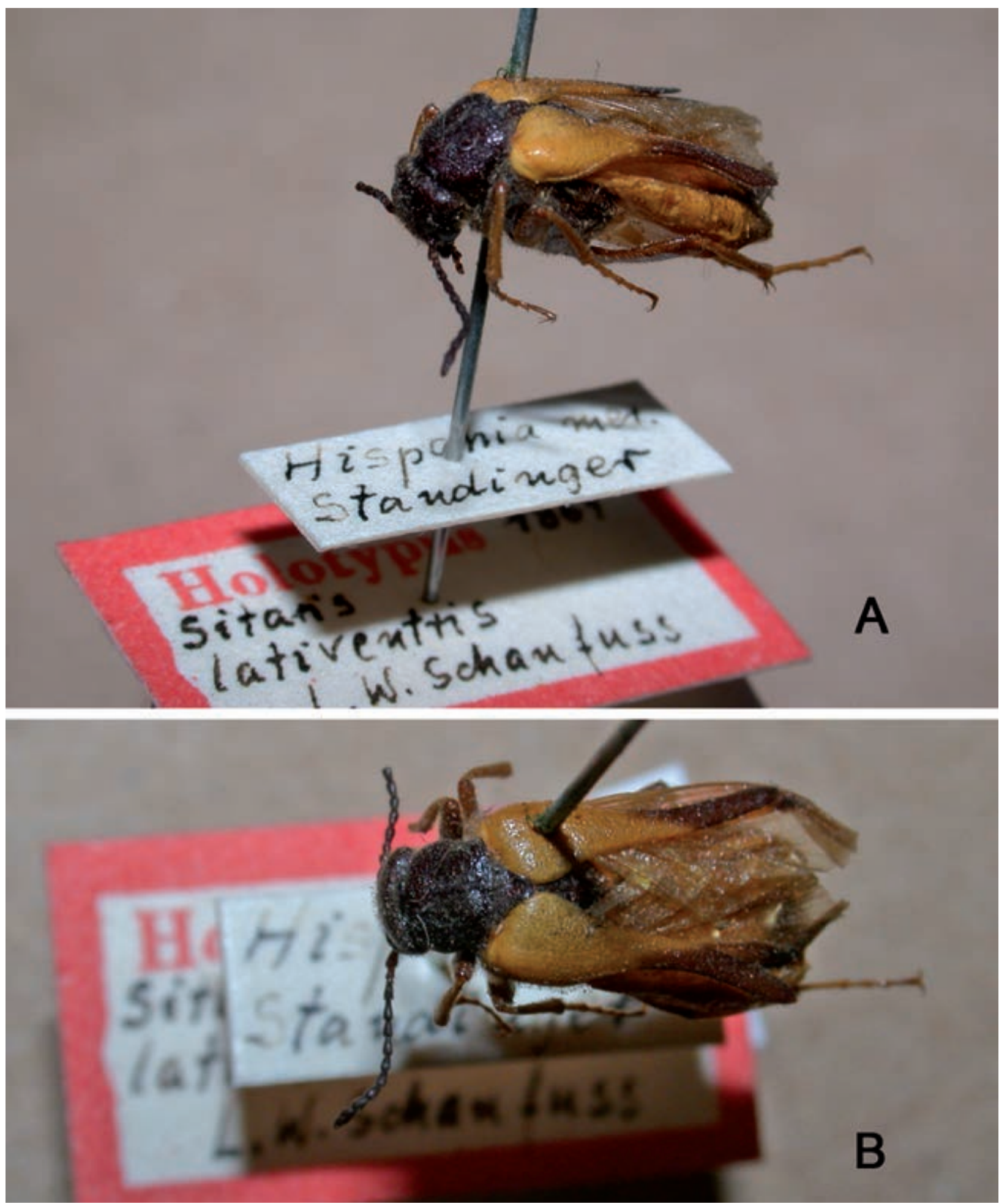

Fig. 2.- Female syntype of $S$. lativentris from "Hispania mer.", held at the collection of the Magyar Természettudományi Múzeum (HNHM, Budapest), here designated as lectotype. A. Lateral view. B. Dorsal view.

Fig. 2.- Sintipo hembra de S. lativentris de "Hispania mer.", conservado en la colección del Magyar Természettudományi Múzeum (HNHM, Budapest), aquí designado como lectotipo. A. Vista lateral. B. Vista dorsal. 


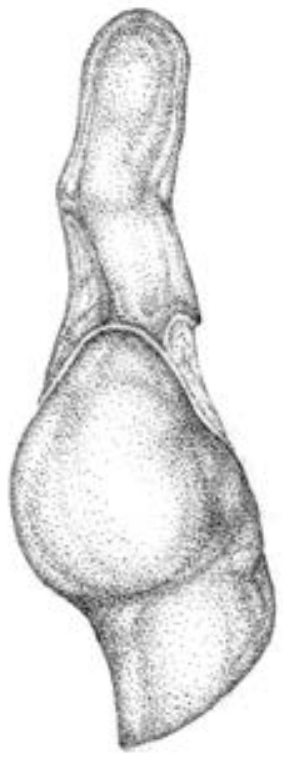

A

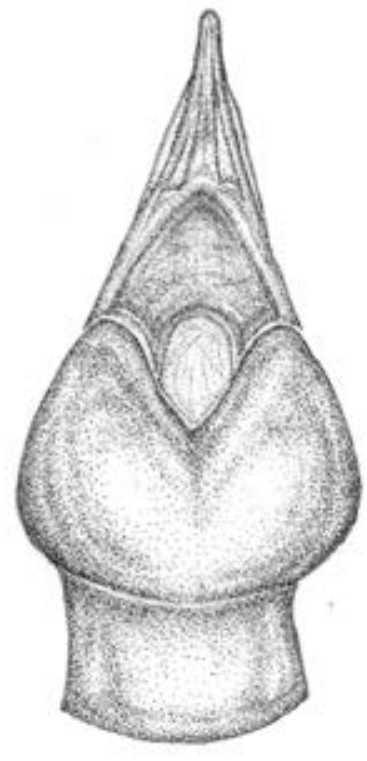

B

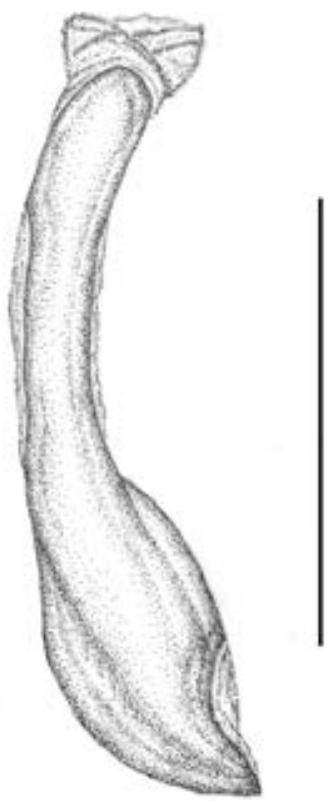

C

Fig. 3.- Male genitalia of Sitaris muralis (Sorvilán, Granada, España): A.- Tegmen lateral view; B.- Tegmen dorsal view; C.Median lobe lateral view. Scale bar: $0.5 \mathrm{~mm}$. (J. L. Ruiz del.).

Fig. 3.- Genitalia masculina de Sitaris muralis (Sorvilán, Granada, España): A.- Tegmen en visión lateral; B.- Tegmen en visión dorsal; C.- Lóbulo medio en visión lateral. Escala: 0.5 mm. (J.L. Ruiz del.).

yellowish, darker in the central area; elytra orangeyellow along the basal two thirds, dark brown along the distal third (the narrowed area of the elytra), the contact between the brown and yellow colour areas is difuse, obliquely placed; wings functional with an amber hue, darker on the sides; abdomen orange-yellow, except a light brown central area in the last sternite; dorsal and ventral pilosity golden yellow, including all the body and appendages, except the apical third of the elytra. Male genitalia identical to that of specimens of $S$. muralis from the same locality, including some variability at the phallobasis and distal portion of aedeagus, broader and lighter in the specimens described (Fig. 3).

Neither the type of $S$. lativentris nor the Sorvilán specimens are similar to $S$. solieri, except in coloration (resembling pale specimens of the latter). Determinant differences between $S$. lativentris and $S$. solieri include: upper blade of tarsal claws ventrally smooth or only with one or few faint teeth at the basis in S. lativentris, strongly dentate along the complete ventral surface in $S$. solieri; male genitalia with the apex of parameri evenly pointed in dorsal view in S. lativentris (Fig. 3), with a lateral narrowing in $S$. solieri. Because these traits are precisely diagnostic characters for the $S$. solieri speciesgroup, $S$. lativentris cannot be considered a synonym of $S$. solieri.

Comparisons between type material of $S$. lativentris and Sorvilán specimens with $S$. muralis, did not render any significant differences, except in the pattern of elytral coloration (similar to pale specimens of $S$. solieri) and coloration of pilosity. Since those coloration characters are variable in other species of Sitaris it is reasonable to assume they may be variable in $S$. muralis as well. Consequently $S$. lativentris and the Sorvilán specimens correspond to a paler phenotype of $S$. muralis with the elytral black colouration slightly reduced anteriorly when compared to typical specimens and with yellow golden vestiture all over the body except on the apical third of the elytra.

The name $S$. lativentris is thus here transferred to the synonym list of $S$. muralis which currenly stands as follows (modified from García-París et al., 2010): 
Sitaris (Sitaris) muralis (Forster, 1771)

Necydalea muralis Forster, 1771: 48

Necydalis humuralis Fabricius, 1775: 209

Necydalis humeralis Fabricius, 1787: 170 (emendation)

Cantharis attenuata Geoffroy in Fourcroy, 1785: 154

Sitaris humeralis (Fabricius, 1775): Westwood, 1839: 297

Sitaris muralis (Forster, 1771): Mulsant, 1857: 191

Sitaris lativentris Schaufuss, 1861: 49 (syn. nov.)

Sitaris splendidus Schaufuss, 1861: 49

Sitaris nitidicollis Abeille de Perrin, 1869: 42

Apalus (Sitaris) muralis (Forster, 1771): Escherich, 1897: 126

Sitaris muralis var. flava Hamm, 1909: 277

Apalus lativentris (Schauffuss, 1861): Borchmann, 1917: 144

Apalus splendidus (Schauffuss, 1861): Borchmann, 1917: 147

Apalus muralis mauritanicus Normand, 1950: 82

The synonymy of $S$. splendidus Schaufuss, 1861, another taxon described from southern Spain (Type locality: "Hisp. mer."; Schaufuss, 1861: 49), with $S$. muralis was subjected to debate: proposed by Escherich (1897), it was not followed by Borchmann (1917) or Mader (1927), but then it was accepted by Bologna (1991, 2008) and García-París et al. (2010). During the present study two syntypes of $S$. splendi$d u s$ (male and female) preserved at HNHM were examined, confirming the synonymy of this species with $S$. muralis. Type labels are as follows: (a) "Hispania mer., Andalusia, Staudinger" (white, rectangular, handwritten); (b) "Holotypus/Paratypus 1861, Sitaris splendidus L.W. Schaufuss" (white with red contour line, rectangular, handwritten, with "Holotypus" and "Paratypus" red printed; added by the Hungarian Museum). The specimens described as $S$. splendidus represent a phenotype in which the extension of the elytral dark colouration is intermediate between typical $S$. muralis and those described as $S$. lativentris. García-París et al. (2010: 193, fig. 11) show a photograph of the syntype of $S$. splendidus labelled as "Holotypus", stating erroneously that it could be the holotype by monotypy. Schaufuss (1861) included more than one specimen in the type series and did not designate a holotype. With the taxonomic purpose of fixing the identity of S. splendidus and in accordance with article 74.7.3 of the International Code of Zoological Nomenclature (ICZN, 1999), we designate here the specimen above mentioned and figured by García-París et al. (2010: 193, fig. 11) as lectotype of $S$. splendidus (present designation). We add to this specimen the following label: "Lectotypus / Sitaris splendidus Schaufuss, 1861 / Ruiz, Bologna \& Ga-París des. 2013" (red printed label).

\section{The identity of Sitaris melanurus Küster, 1849}

Sitaris melanurus was described (as Sitaris melanura) from southern France and Spain (Type locality: "Südfrankreich und Spanien") (Küster, 1849a). The identity of this enigmatic taxon escaped the attention of most researchers on the group, which simply retained the name as a valid taxon from catalogue to catalogue without discussion (Beauregard, 1890; Rodríguez López-Neyra, 1914; Borchmann, 1917; Mader, 1927; Bologna, 2008), or with vague statements about its taxonomic value (Escherich, 1897: 132; Pardo Alcaide, 1958: 21; García-París et al., 2010: 193). The species has not been found since its original description, despite the relatively wide geographic range deduced from the type locality (Pardo Alcaide, 1958; García-París, 2000). To complicate matters, the type specimens seem to be lost (pers. com. M. Balke, Zoologische Staatssammlung, Munich).

However, the original description is quite detailed and provides sufficient basis to discard the inclusion of the taxon in Sitaris. As a matter of fact, statements presented in the description like "Brustschild wie der Kopf rostgelb, glänzend (...), der Grund rostgelb, mit einem schwarzen punktformigen Fleckchen auf der Mitte der Basin", "Beine lang, schwach, rostgelb" (sic), and many others, correspond to traits that, among western European sitarine beetles, are only present in Stenoria apicalis (Latreille, 1804) (Pardo Alcaide, 1958; Bologna, 1991). Therefore it is likely that Küster (1849a) was describing one of the most frequent color variants of this species (pronotum yellow-reddish with a basal central dark spot; Bologna, 1991). The geographic range of $S$. apicalis (see Bologna, 1991, 2008; Ruiz, 2001) includes the range indicated in the original description for $S$. melanurus, adding support to our taxonomic subjective statement.

As a consequence we include the name $S$. melanurus as a new synonym in the synonym list of $S$. apicalis as follows (modified from García-París et al., 2010):

\section{Stenoria (Stenoria) apicalis (Latreille, 1804)}

Sitaris apicalis Latreille, 1804: 403

Sitaris melanura Küster, 1849a: 84 syn. nov.

Ctenopus sturmii Küster, 1849b: $\mathrm{n}^{\circ} 72$

Stenoria apicalis (Latreille, 1804): Mulsant, 1857: 186

Stenoria kraatzii Mulsant et Rey, 1861: 191

Hapalus (Stenoria) apicalis (Latreille, 1804): Procházka, 1892:

269 
Apalus (Stenoria) apicalis picicollis Escherich, 1897: 123

Stenoria brunneicollis Pic, 1914: 74 (this synonymy requires further study)

Apalus melanurus (Küster, 1849): Borchmann, 1917: 144

Stenoria apicalis ab. basicollis Kaszab, 1956: 158 (name not available)

Stenoria apicalis ab. vitticollis Kaszab, 1956: 158 (name not available)

Stenoria apicalis ab. bipunctata Kaszab, 1956: 158 (name not available)

Stenoria apicalis ab. communimacula Kaszab, 1956: 159 (name not available)

Stenoria apicalis ab. nigroplagiata Kaszab, 1956: 159 (name not available)

Stenoria apicalis ab. tristicula Kaszab, 1956: 160 (name not available)

Stenoria apicalis ab. paucinigra Pardo Alcaide, 1958: 17 name not available)

Stenoria apicalis ab. kaszabiana Pardo Alcaide, 1958: 17 name not available)

Stenoria apicalis ab. catalonica Pardo Alcaide, 1958: 18 (name not available

Stenoria apicalis ab. luteifrons Pardo Alcaide, 1958: 18 (name not available)

Stenoria apicalis var. iranica Kaszab, 1959: 440 (this synonymy requires further study)

\section{Acknowledgments}

Our work would have not been possible without the help of the curators of the scientific collections and researchers of the institutions visited: Ottó Merkl and Judit Vörös (Magyar Természettudományi Múzeum, Budapest), Mercedes París (Museo Nacional de Ciencias Naturales), and Jesús Benzal (Estación Experimental de Zonas Áridas). We also thank Pablo Barranco, Pablo Bercedo and Lucía Arnáiz for their kind collaboration. This work has been supported by grants CGL200404680-C10-10 (Fauna Ibérica) and CGL2010-15786 of the Ministerio de Economía y Competitividad (Spain).

\section{References}

Abeille de Perrin, E., 1869. [Sitaris nitidicollis n. sp.]. Petites Nouvelles Entomologiques, 1(11): 42.

Beauregard, H., 1890. Les insectes vésicants. Félix Alcan. París. i-xvi, 1-544, 34 láms.

Bologna, M. A., 1991. Fauna d'Italia. XXVIII. Coleoptera Meloidae. Edizioni Calderini. Bologna. 541 pp.

Bologna, M. A., 1994. I Meloidae della Grecia (Coleoptera). Fragmenta Entomologica, 25, Supplemento: 1119.

Bologna, M. A., 2008. Family Meloidae Gyllenhal, 1810. In: I. Löbl \& A. Smetana (eds.) Catalogue of Palaearctic Coleoptera. Volume 5. Tenebrionoidea. Apollo Books. Stenstrup: 45-49 and 370-412.

Bologna, M. A. \& Aberlenc, H.-P., 2002. Allendesalazaria, un nouveau genre de Meloidae pour la faune saharien- ne (Coleoptera). Bulletin de la Société entomologique de France, 107(2): 191-192.

Bologna, M. A., Oliverio, M., Pitzalis, M. \& Mariottini, P., 2008. Phylogeny and evolutionary history of the blister beetles (Coleoptera, Meloidae). Molecular Phylogenetics and Evolution, 48(2): 679-693.

Bologna, M. A. \& Pinto, J. D., 2002. The Old World genera of Meloidae (Coleoptera): a key and synopsis. Journal of Natural History, 36(17): 2013-2102.

Borchmann, F., 1917. Pars 69. Meloidae, Cephaloidae. In: E. Schenkling (ed.). Coleopterorum Catalogus auspiciis et auxilio W. Junk. Junk. Berlin. 208 pp.

Escherich, K., 1897. Bestimmungs-Tabelle der europäischen Coleopteren. Meloidae. II. Theil: Zonitidae. 36 Heft. Revision der palaarktischen Zonitiden, einer Unterfamilie der Meloiden. Verhandlungen des naturforschenden Vereines in Brünn, 35: 96-133.

Fabricius, J. C., 1775. Systema entomologiae. Sistens Insectorum classes, ordines, genera, species etc. Korte. Flesburgi et Lipsiae. xxx +832 pp.

Fabricius, J. C., 1787. Mantissa insectorum sistens eorum species nuper detectas adiectis characteribus generis, differentiis specificis, emendationibus observationibus. Tom. 1. Christ. Gottl. Proft. Hafniae. $\mathrm{xx}+348 \mathrm{pp}$.

Forster, J. R., 1771. Novae species insectorum. Centuria I. London. 100 pp.

García-París, M., 2000. Nuevas localidades de Sitarini (Col. Meloidae) de la Península ibérica. Boletín de la Asociación Española de Entomología, 24: 197-200.

García-París, M. \& Ruiz, J. L., 2011. Las cantáridas y aceiteras (Coleoptera: Meloidae) en la obra de M. Martínez de la Escalera. In: C. Martín Albaladejo, C. \& I. Izquierdo Moya (eds.). Al encuentro del naturalista Manuel Martínez de la Escalera (1867-1949). Monografías, Museo Nacional de Ciencias Naturales, $\mathrm{n}^{\mathrm{o}} 25$. Consejo Superior de Investigaciones Científicas. Madrid: 173-205, láms. 9-14.

García-París, M., Ruiz, J. L. \& Alonso-Zarazaga, M. A., 2010. Catálogo sinonímico de los táxones ibero-baleares de la familia Meloidae (Coleoptera). Graellsia, 66(2): 165-212.

Geoffroy, E. L., 1785. [New taxa] In: A. F. de Fourcroy. Entomologia Parisiensis, sive catalogus Insectorum, quae in Agro Parisiensi reperiuntur; Secundum methodum Geoffroeanam in sectiones, genera et species distributus: ci addita sunt nomina trivalia et fere trecentae novae Species. Pars Prima. Serpentineis. Paris. vii $+231+233-544$ pp.

Hamm, A. H., 1909. Sitaris muralis, Forst., n. var. flava. The Entomologist's Monthly Magazine, 45: 277.

ICZN (International Commission on Zoological Nomenclature), 1999. International Code of Zoological Nomenclature. 4th ed. International Trust for Zoological Nomenclature. London. 306 pp. 
Kaszab, Z., 1953. Studien über südafrikanischen Meloiden (Coleoptera). Annals of the South African Museum, 40: 61-79.

Kaszab, Z., 1956. Neue Meloiden-, Alleculiden-, Serropalpiden-, Anthiciden- und Oedemeriden-Formen aus Ungarn und dern angrezenden Gebieten (Coleoptera). Folia Entomologica Hungarica (series nova), 9(5): 141-172.

Kaszab, Z., 1959. Eine neue Meloiden-Art und einige neue Formen der Koleopteren-Sammlung des Naturhistorischen Museum in Wien. Annalen des Naturhistorischen Museums in Wien, 63: 436-441.

Kaszab, Z., 1963. Studien über Meloiden (Coleoptera). Annales Historico-Naturales Musei Nationalis Hungarici, Pars Zoologica, 55: 335-346.

Küster, H. C., 1849a. Die Käfer Europa's. Nach der Natur beschrieben. Mit Beiträgen mehrerer Entomologen. 16 heft. Bauer e Raspe. Nürnberg. pp. 82-84.

Küster, H.C., 1849b. Die Käfer Europa ’s. Nach der Natur beschrieben. Mit Beiträgen mehrerer Entomologen. 5 heft. Bauer e Raspe. Nürnberg. pp. 72.

Latreille, P. A., 1804. Histoire naturelle, générale et particulière des Crustacés et des Insectes. Ouvrage faisant suite à l'Histoire naturelle générale et particulière par Leclerc et de Buffon et partie du cours complet d'Histoire naturelle rédigé par C.S. Sonini. Tomo 10. Dufart. Paris. xii +415 pp.

MacSwain, J. W., 1956. A classification of the first instar larvae of the Meloidae (Coleoptera). University of California Publications in Entomology, 12: 1-182.

MacSwain, J. W. 1958. Taxonomic and biological observations on the genus Hornia (Coleoptera: Meloidae). Annals of the Entomological Society of America, 51: 390-396.

Mader, L., 1927. Meloidae. In: A. Winkler (ed.). Catalogus Coleopterorum regionis palaearcticae. II. Winkler. Wien: 851-888.

Martínez de la Escalera, M., 1906. Especies nuevas de Coleópteros de Marruecos. Boletín de la Real Sociedad española de Historia Natural 6: 161-163.

Mulsant, E., 1857. Histoire naturelle des Coléoptères de France. Vésicants. Magnin, Blanchard et Cie. París. $201+9$ pp., 1 lám.

Mulsant, E. \& Rey, C., 1861. Description de deux Coléoptéres nouveaux ou peu connus. Opuscules Entomologiques, 12: 189-192.

Normand, H., 1950. Contribution au catalogue des Coléoptères de la Tunisie. Troisième supplement (Fascicule 4). Bulletin de la Société des Sciences Naturelles de Tunisie, [1949], 2: 79-104 + lám. 6-7.

Pardo Alcaide, A., 1958. Analéctas entomológicas. VII. Los Sitarini de la fauna ibérica (Col. Meloidae). Graellsia, 16: 13-22.

Pardo Alcaide, A., 1961. Estudios sobre "Meloidae". XIII. Meloideos del Sáhara occidental español y de la región del Drâa (Marruecos) (Coleoptera). Eos, 37: 91-111.

Pic, M., 1914. Notes diverses, descriptions et diagnoses (Suite). L'Échange, Revue Linnéenne, 30(359): 73-75.

Pinto, J. D. \& Bologna, M. A., 1999. The New World genera of Meloidae (Coleoptera): a key and synopsis. Journal of Natural History, 33: 569-620.

Procházka, J., 1892. Revision der Arten der ColeopterenGattung Hapalus Fabr. aus der paläarctischen Fauna. Wiener Entomologische Zeitung, 11: 263-270.

Rodríguez López-Neyra, C., 1914. Claves dicotómicas para la determinación de los meloideos indígenas. Boletín de la Real Sociedad Española de Historia Natural, 14: 461-475.

Ruiz, J. L., 2001. Las Stenoria Mulsant, 1857 del grupo de $S$. apicalis (Latreille, 1802) de la Península Ibérica (Coleoptera, Meloidae). Graellsia, 57(2): 161-173.

Schaufuss, L.W., 1861. Ueber 22 zum Theil neue Käferarten. Sitzungs-Berichte und Abhandlungen der Naturwissenschaftlichen Gesellchaft Isis zu Dresden, 1861: 47-51.

Schaufuss, L. W., 1870. Coleopterologisches. Numquam Otiosus. Zoologische Mittheilungen, 1: 29-49.

Schawaller, W., 1996. Stenoria thakkola sp. n., the first species of the tribe Sitarini from the Himalayas (Coleoptera: Meloidae). Elytron, 10: 147-152.

Westwood, J. O.. 1839. An introduction to the modern classification of Insects; founded on the natural habits and corresponding organisation of the different families. Vol. 1. Longman. London. $12+462$ pp., 1 lám.
Recibido / Received, 2-11-2012 Aceptado / Accepted, 24-10-2013 Publicado impreso / Published in print, 30-12-2013 
Appendix I.- Additional non type material examined of S. muralis and S. solieri from Spain. EEZA: Estación Experimental de Zonas Áridas (CSIC-Almería); JLR: J.L. Ruiz collection (Ceuta); MGP: M. García-París alcohol collection at MNCN; MNCN: Museo Nacional de Ciencias Naturales (CSIC-Madrid); PB: P. Bercedo \& L. Arnáiz collection (Devesa de Cureño, León).

Apéndice I.- Material adicional, no tipo, examinado de S. muralis y S. solieri de España. EEZA: Estación Experimental de Zonas Áridas (CSIC-Almería); JLR: colección J.L. Ruiz (Ceuta); MGP: colección en alcohol de M. García-París, depositada en el MNCN; MNCN: Museo Nacional de Ciencias Naturales (CSIC-Madrid); PB: colección P. Bercedo \& L. Arnáiz (Devesa de Cureño, León).

\section{Sitaris muralis}

Almería: Sierra de María, Refugio, 1400 m., 30SWG724719: 14-VIII-1990, 1 male, (P. Barranco leg.) [JLR]. Barcelona: Pedralbes: 18-XI-1897, 1 specimen (A. Cabrera leg.) [MNCN]. Cantabria: Miera: 20-IX-1984, 1 male (ahogado en un abrevadero) (P. Bercedo leg.) [PB]. Ciudad Real: Pozuelo de Calatrava: 1 specimen (Seebold leg.). [MNCN]. Granada: Barranco del Espartal, Cúllar-Baza, 30SWG2754: 22-IX-1991, 1 male (F.S. Piñero leg.); 1 km SO Cádiar: 14-IX-2006, 9 specimens (M. García-París leg.) [MNCN-MGP field number: 06260]; Sorvilán: 12-IX-2005, 3 males (J.L. Ruiz leg.) [JLR]; Sorvilán: 14-IX-2006, 5 specimens (M. García-París leg.) [MNCN-MGP field number: 06259]. Madrid: El Escorial: 1 specimen (A. Cobos leg.) (Sitaris muralis Pardo Alcaide det. 1951) [EEZA]; 4 km S de Tielmes: 28-IX-2003, 1 specimen, 5IX-2004, 5 specimens [MNCN-MGP field number: 04244 245, 08288]; Villaviciosa: 1 specimen (J. Ardois leg.)
[MNCN]; Villaviciosa: 20-VIII-193?, 1 specimen [MNCN]. Málaga: 1 specimen (Aragoncillo leg.) (Col. del Sr. Pérez Arcas). [MNCN]. Navarra: Corella: 1 specimen (Sitaris muralis Pardo Alcaide det. 1957) [EEZA]. Sevilla: Cazallas: 1 specimen (Calderón leg.) [MNCN]. Zaragoza: Tauste: 9-IX2004, 1 specimen, escaped (M. García París photograph); Zaragoza: 1 specimen (Aranda leg.) [MNCN].

\section{Sitaris solieri}

Ávila: Villarejo it. [del Valle]: 1 specimen [MNCN]. Jaén: Santiago de la Espada: 1 specimen (J. Martínez leg.) [MNCN]. Sevilla: Osuna: 1 specimen (Rico leg.) [MNCN]. Tenerife: Bajamar: X-1921, 1 specimen (A. Cabrera leg.) [MNCN] [see García-París \& Ruiz, 2011, for additional material included in the type series of $S$. solieri var. cabrerai Martínez de la Escalera, 1921]. 